\title{
The impact of the spread of covid-19 on marine tourism-based small businesses and suggested recovery plans
}

\author{
Syafruddin Chan $^{1 *}$, and Kurnia Asni $^{2}$ \\ ${ }^{1}$ Management Department, Syiah Kuala University, Banda Aceh, 23111, Indonesia \\ ${ }^{2}$ Master in Management Department, Abulyatama University, Aceh Besar, 23272, Indonesia
}

\begin{abstract}
The purpose of this study is to find out the real impact of the COVID-19 epidemic on tourismbased small businesses in the island, as well as what recovery strategies that should be undertaken from the standpoint of company owners, including potential for leveraging digital business technology. This research was conducted using a quantitative descriptive method. Data collected using online questionnaires. 50 questionnaires distributed using non-probability sampling. The distribution of Covid-19 had a detrimental effect on the small companies who participated in this study. The greatest consequence is a decrease in revenues due to a decrease in demand for its products and services. As a result, firms downsized by reducing their business scale and laying off staff. Companies are beginning to employ technology to enter digital industries, such as joining online apps and selling more aggressively in e-markets. Virtual reality tour business opportunities can be tried to generate alternative income.
\end{abstract}

\section{Introduction}

Throughout 2020, the Covid-19 pandemic has caused an economic crisis throughout the world. Not only experienced by developing countries and countries categorized as poor, developed countries also feel the negative impact of the outbreak of Covid-19. Most developed countries as well as developing countries are even caught in a deep economic recession. Only a handful of countries in the world are still able to survive and grow positively to face the impact of the Covid-19 pandemic in 2020, namely China (2.3 percent), Vietnam (2.9 percent), and Taiwan (2.98 percent) [1].

Outside of these three countries, the Covid-19 pandemic has ravaged the economies of countries in the world, including developed countries, such as the United States (US), Germany, Britain, and Japan. The United States (US) economy was recorded to have shrunk to minus 3.5 percent in 2020 . Germany grew by negative 5 percent. Britain contracted 9.9 percent. Japan shrank 4.8 percent. Meanwhile, France and Italy closed 2020 with contractions of 8.2 percent and 8.9 percent, respectively. In Southeast Asia, only Vietnam grew positively by 2.91 percent in 2020. Meanwhile, other countries in the ASEAN region grew negatively. Singapore contracted 5.4 percent, Malaysia minus 5.6 percent, and Thailand minus 6.1 percent. Meanwhile, the Philippines was the worst because its economy contracted by 9.5 percent in 2020 [1].

A number of international institutions predict that global economic growth in 2020 is predicted to fall deeper than in previous years. In January 2021, the IMF estimates global economic growth at minus 3.5 percent. Meanwhile, the World Bank in January 2021 and the
OECD in December 2020 each predicted a deeper decline in global economic growth to minus 5.2 percent and minus 4.2 percent. The sluggish global economy cannot be separated from the effects of the Covid-19 pandemic which has spread to world economic and financial problems. His sudden arrival put great pressure on the supply and demand sides. The world's production chain is not only disrupted, it is even cut off, because many countries choose regional quarantine (lockdown) to contain the spread of Covid-19 [2].

The impact of the COVID-19 pandemic has also spread to Indonesia. The World Bank projects that Indonesia's gross domestic product (GDP) growth throughout 2021 will reach 4.4 percent after the previous year's contraction of 2.1 percent. This economic recovery depends on the effectiveness of the Covid-19 control program and the government's ability to take advantage of the momentum of the global market revival. This has a very serious impact because the trade sector tax revenue has a major contribution in boosting state revenues, precisely which is in the second largest [3]. This pandemic has also greatly affected market projections. Investors may tend not to invest due to changing market assumptions and unclear supply chains [4]. The impact of COVID-19 on the tourism sector is also not without threats. Data compiled from the Central Statistics Agency explains that in 2019 foreign tourists from China who came to Indonesia touched 2.07 million travellers or $12.8 \%$ of the total number of foreign tourists throughout 2019. The COVID-19 pandemic resulted in a decline in tourists coming to Indonesia. Tourism supporting sectors, namely restaurants, hotels and retail entrepreneurs are also affected by the COVID-

\footnotetext{
*Corresponding authors: syafruddin.chan@unsyiah.ac.id
} 
19 pandemic. Hotel profits have decreased by up to $40 \%$ so that it has an impact on hotel operations and threatens the continuity of its business. The decline in foreign visitors also affects the income of restaurants or restaurants whose customers are more dominantly visitors from abroad [3].

The COVID-19 pandemic has also affected the micro, small and medium business sector in the tourism sector. This is because foreign visitors who come to a destination will usually buy souvenirs to take home [5]. Other micro businesses in the tourism industry that have been affected by the COVID-19 pandemic include diving and snorkeling businesses, culinary businesses, lodging accommodations, laundry services, communication services, retail and many others. If foreign visitors visit decrease, it is certain that the income for micro, small and medium enterprises will also decrease [6]. Bank Indonesia has released data in 2016 regarding the micro, small and medium enterprises sector which states that the enterprises are the most vulnerable business during pandemic

For business entities, the loss of income is due to no sales, but expenses still occur, although not completely. Real losses will vary depending on what type of expenditure is being made. Among the expenses that are relatively fixed are the rent of the place (or depreciation of the building if it is self-owned) along with the routine costs that accompany it, salaries of staff who cannot be laid off for various reasons, security, payments to suppliers that can no longer be postponed and so on. Another impact is the emergence of fines/penalties due to inaccuracy in delivery times [7]. Damage to goods if stuck in the warehouse or on the road, or payment of additional premiums when applying insurance. Another impact is the emergence of severance costs if you are laid off. Fines/interests arise when using bailout funds or debts, or if they are unable to pay in accordance with the provisions of the amount and time. Losses if the company is forced to sell assets at low prices. A priceless loss if the crisis causes the company's capital to be drained so that the scale of the business shrinks or even goes bankrupt. However, the company may have income from previous sales invoices, which can still reduce the loss or budget deficit in the current month. With a successful billing record, the client is able to pay according to the provisions [7]. A priceless loss if the crisis causes the company's capital to be drained so that the scale of the business shrinks or even goes bankrupt. However, the company may have income from previous sales invoices, which can still reduce the loss or budget deficit in the current month. With a successful billing record, the client is able to pay according to the provisions [7-8]. A priceless loss if the crisis causes the company's capital to be drained so that the scale of the business shrinks or even goes bankrupt. However, the company may have income from previous sales invoices, which can still reduce the loss or budget deficit in the current month. With a successful billing record, the client is able to pay according to the provisions [9].

The purpose of this study is to find out the real impact of the COVID-19 epidemic on tourism-based small businesses in the weh island, as well as what recovery strategies that should be undertaken from the standpoint of company owners, including potential for leveraging digital business technology.

\section{The Government's Response to Help MSMEs against the Pandemic}

When the Covid-19 outbreak spread throughout the world, a number of countries struggled to contain the spread and contain the outbreak. Governments around the world are seeking to implement extraordinary policy measures to save lives and protect the livelihoods of people hit hard by the Covid-19 pandemic. In terms of handling the pandemic, the governments of countries generally carry out a combination of $3 \mathrm{M}$ (maintaining distance, wearing masks, washing hands) and $3 \mathrm{~T}$ (testing, tracing, treatment) as well as social distancing policies to regional closures. In terms of handling economic impacts, various policies are directed at three priorities, namely providing funds for health care, distributing social safety net assistance, and providing economic stimulus/support to the business world [10$11]$.

Governments of countries in the world generally provide stimulus either through monetary policy or fiscal policy. In the monetary sector, the policy of lowering interest rates is carried out by almost all over the world. This was done with the aim of encouraging economic activity, both on the consumption and investment side, by reducing bank lending rates. The policy is expected to continue in 2021. The central bank will tend to lower or maintain interest rates due to the ongoing economic recovery period [12].

Just like other countries, Indonesia has also taken several steps to reduce the effects of the COVID-19 pandemic, including reducing the BI 7-Day Reverse Repo Rate by 25 bps to $4.75 \%$, the Deposit Facility interest rate by 25 bps to $4.00 \%$ and the interest rate on the Deposit Facility by 25 bps to $4.00 \%$. Lending Facility interest rate of 25 bps to $5.50 \%$. This measure was implemented to stimulate domestic economic growth amidst the delayed prospects of global economic recovery due to the COVID-19 pandemic. In addition, to keep inflation and external stability under control and to strengthen the momentum of economic growth, Bank Indonesia must be able to observe global and domestic economic developments [2] and [7].

Overall, the response made by the Indonesian government during this pandemic, especially against MSMEs, including those engaged in the tourism sector, can be broken down into five schemes, namely (1) Social support; (2) SMES tax incentives; (3) Credit restructuring and relaxation (4) Working capital support stimulus; and (5) Collaboration with State-owned enterprise as the off-taker for SMES products. On the other hand, there are some SMES business strategies in adjusting amidst the Covid-19 pandemic in Indonesia. Those strategies are (1) Products innovation; (2) Customer and stakeholder relationship management (3) Digital marketing and distribution; and (4) Strategic Agile [12].

For small and medium enterprises which are categorized as poor and vulnerable to being affected by 
Covid-19. Efforts made to ensure that business actors in this scheme become recipients of social assistance from the Government. According to Minister of Social Affairs Number 1/2018, Government must ensure that they are included as part of the recipients of social support namely PKH (Family Hope Program), food packages, cash assistance, direct cash support, as well as exemption from reducing electricity rates and preemployment cards. The second scheme is a scheme regarding tax incentives that applies to SMES actors with a turnover revenue of below Rp. 4.8 billion per year (12). The Government has lowered the final income tax rate (the final Income Tax (tax income) or PPh rate for SMEs from 0.5 to 0 per cent over six months starting from April to September 2020 this policy written in Minister of Finance Regulation Number 44/PMK.03/2020. The third scheme is relaxation and SMES credit restructuring. This scheme includes the postponement of installations and interest subsidies for recipients of KUR (People's Business Credit), UMi (Ultramicro Credit), PNM Mekaar (Fostering Prosperous Families), LPDB (revolving fund management institutions), and recipients of capital support from several ministries. The Government will also impose expansion financing support for SMEs, in the form of working capital assistance stimulus. The Government prepares emergency working capital assistance designed explicitly for SMES entrepreneurs who are severely impacted by Covid-19. The data shows that currently, there is 41 million SMES business have already connected with financial institutions and banks. Meanwhile, there are still 23 million SMEs who have never received financing from financial institutions or the banking system. Therefore, for SMEs that are bankable, the financial support distribution will go through the expansion of the KUR program and at the same time encourage financial inclusion. On the other hand, for those who are not bankable, the distribution can be done through UMi, Mekaar, or other program schemes [12]. For SMEs that are bankable, the financial support distribution will go through the expansion of the People's Business Credit (KUR) program and at the same time encourage financial inclusion. On the other hand, for those who are not bankable, the distribution can be done through Ultra Micro Financing (UMi), Fostering the Economy of Underprivileged Families (Mekaar), or other program schemes [12].

\section{Opportunities in the Pandemic Era for MSMEs}

The spread of the Covid-19 outbreak in Indonesia has caused the Government to urge the public to limit physical contact. Daily activities such as work, study, and worship are recommended to be done at home. This limitation of physical contact, aka physical distancing, has a significant impact on many parties, one of which is business people. Not a few business actors, ranging from the SME level to large scale, have revealed a decline in income over the past few weeks. However, my friend as a business actor, of course, should not give up. In the midst of the widespread spread of Covid-19, it turns out that there are still promising business alternatives [13].

The Covid-19 pandemic is indeed quite influential on business continuity and is considered to bring changes in business going forward, especially in consumer behavior and consumption. However, working and doing business from home (Work Form Home - WFH) apart from being a limitation, it also brings opportunities. This period of social distancing can be an opportunity to optimize business strategies. This encourages the importance of identifying consumption and consumer behavior in producing goods needed by the community. In addition, it is also a momentum for the development of the digital and creative economy.

As we all know, the tourism sector is the sector most severely affected by the COVID-19 pandemic. The existence of new business opportunities in the pandemic era can be used as a momentum to rise and take advantage of existing opportunities to increase income. For SMEs who are engaged in the culinary field, which previously served mostly tourists, now they can join delivery businesses such as Gojek and Go Food to serve the domestic community. The types of food sold can also be expanded by serving other frozen food, homemade side dishes packaged in bottles, pastries and drinks such as milk coffee, and others.

\section{Methodology}

In contrast to the previous section, which was conducted through a literature review, this section uses primary data. The population of this study are small businesses engaged in the tourism industry, especially marine tourism on Pulau Weh, Aceh, Indonesia. Data were collected using an online questionnaire. The respondents were MSMEs with 50 (fifty) questionnaires distributed using non-probability sampling. NonProbability Sampling is a technique of taking data or samples so that all data selected as samples are not the same size. Based on the researcher's policy in determining the sample elements to be used

\section{Entrepreneur Response for Business Recovery}

The spread of the Covid-19 outbreak in Indonesia has caused the government to urge the public to limit physical contact. Daily activities such as work, study, and worship are recommended to be done at home. This limitation of physical contact, aka physical distancing, has a significant impact on many parties, one of which is business people. Not a few business actors, ranging from the MSME level to the enterprise level, have revealed a decline in sales over the past few weeks. In line with changes in people's behavior, the Online Shop is excellent. Before the emergence of the Covid-19 case in Indonesia, online business had indeed become one of the solutions because it was easy for customers to shop without being limited by distance and time. Despite having to limit store opening hours due to physical distancing [4]. 
One of the most significant determinants of the success of SMEs during this pandemic is their flexibility in paying attention to customer needs and expectations. When there are drastic changes due to this pandemic, many business models or businesses cannot survive, but new opportunities will be created. Under these conditions, it is understandable that SMEs are very difficult to focus on identifying and exploring new opportunities by losing profits, customers and even key employees. However, with the survival of SMEs at stake, owners must exercise resilience and adopt a mindset to recognize and identify opportunities to bounce back and move forward. Thinking positively in the midst of difficult times is not always easy. However, adaptation and flexibility are the main keys that must be held by anyone who is in the hospitality \& tourism industry. After all, change is the only thing that keeps happening in the world. So, changing the strategy to be able to survive during the pandemic is a realistic step that tourism activists can take.

Just like other sectors, SME business actors in the tourism sector must also be creative to innovate their offerings, so that they can still exist in today's difficult times. However, the role of the government or other parties is still expected to help these SMEs get out of the crisis due to the impact of the COVID-19 pandemic.

When asked if you have ever received assistance, to help your company avoid business difficulties? So, $46 \%$ answered yes and 54\% answered no.

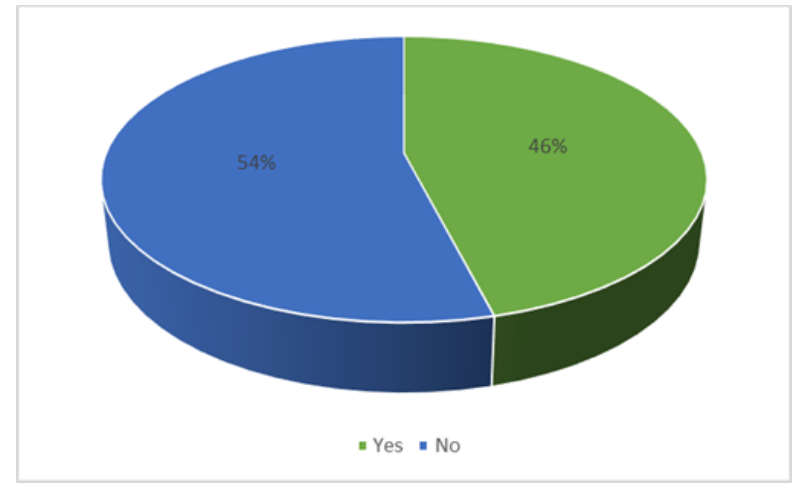

Fig. 1. Is there any Receiving Help?

To those who answered yes, they were asked what kind of assistance they had received. So, 17\% said they had the opportunity to have a CHSE (Cleanliness, Health, and Safety \& Environment Sustainability) certificate which is a certificate of recognition for the implementation of Cleanliness, Health, and Safety \& Environment Sustainability in their business units. Cleanliness, Health, Safety \& Environment Sustainability (CHSE) certification is given to owners/managers of tourism businesses and tourism destinations from all over Indonesia for free by the Ministry of Tourism and Creative Industries (Kemenparekraf).

All stages of the certification process are financed by the Ministry of Tourism and Creative Economy, so that the costs are not charged to the destination managers and tourism businesses. The use of CHSE is a guarantee to tourists and the public that the products and services provided have complied with the hygiene, health, safety, and environmental sustainability protocols. Because the key to the successful recovery of the tourism sector and the creative economy is the application of standard health protocols in the tourism sector. The certificate, known as Indo Care, which stands for Indonesia Care, provides certification for hospitality businesses, restaurants, tourist attractions, white water rafting, home stays, diving, tourism transportation businesses, and sports recreation such as golf clubs, Spa business and other Creative Economy Business Because the key to the successful recovery of the tourism sector and the creative economy is the application of standard health protocols in the tourism sector. The certificate, known as Indo Care, which stands for Indonesia Care, provides certification for hospitality businesses, restaurants, tourist attractions, white water rafting, home stays, diving, tourism transportation businesses, and sports recreation such as golf clubs, Spa business and other Creative Economy Business Because the key to the successful recovery of the tourism sector and the creative economy is the application of standard health protocols in the tourism sector. The certificate, known as Indo Care, which stands for Indonesia Care, provides certification for hospitality businesses, restaurants, tourist attractions, white water rafting, home stays, diving, tourism transportation businesses, and sports recreation such as golf clubs, Spa business and other Creative Economy Business.

Other assistance they received was staple food $(26 \%)$, to ease the burden of the cost of meeting basic needs for tourism practitioners during the pandemic. Then through the Provincial Tourism Office.

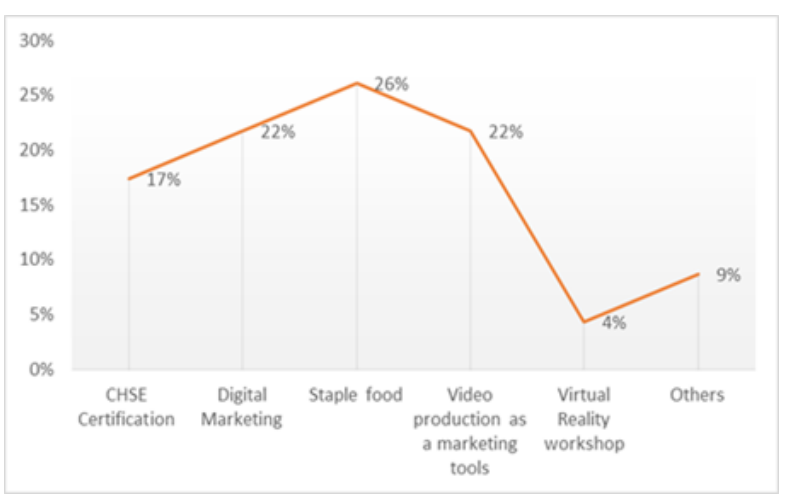

Fig. 2. What assistance have you received?

Aceh, tourism actors receive digital marketing training $(22 \%)$, especially for those who are engaged in the souvenir business, then training on making video marketing $(22 \%)$ as a tool in marketing their business units, as well as virtual workshop training (4\%) aimed at enabling tourists to enjoy tourist destinations in a fun way without having to come to the physical location of the destination.

It has been more than a year that the pandemic has hampered the running of business in all sectors. So far there is no sign of abating. The number of people exposed to and infected with the Corona virus continues to grow. Most tourism actors view pessimism that this suffering will end in the near future. They really hope that there will be further assistance provided by the government so that the difficulties they face can be 
helped a little. When asked what form of assistance they expect from the government, the answer can be seen in the following figure:

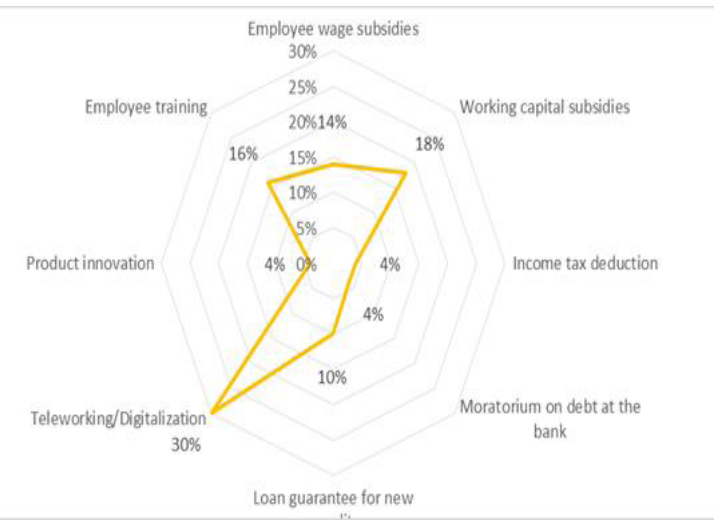

Fig.3. what help do you expect from the government?

Most of them (30\%) expect assistance in digitizing their business to take advantage of increasingly promising online business opportunities. Meanwhile, other respondents expect the subsidies for their employees' wages which are still maintained at the current company (18\%). There are also those who ask for the scheduling of bank loan repayments for the loans they have made $(10 \%)$ as well as a reduction in income tax if possible (4\%).

The next question is what he has done in the past year to keep his business afloat. They stated that they had started to take advantage of the online business by opening an online shop to sell their products, especially souvenir products $(30 \%)$. Another respondent stated that what they were doing was cost efficiency to keep the company's cash flow liquid (20\%). There are also those who have tried to obtain additional loans as additional working capital (20\%). Meanwhile, other respondents have diversified their business outside the tourism sector, such as the fishing business $(16 \%)$ and $10 \%$ of the respondents have laid off their employees, and hope to re-employ them when the situation improves.

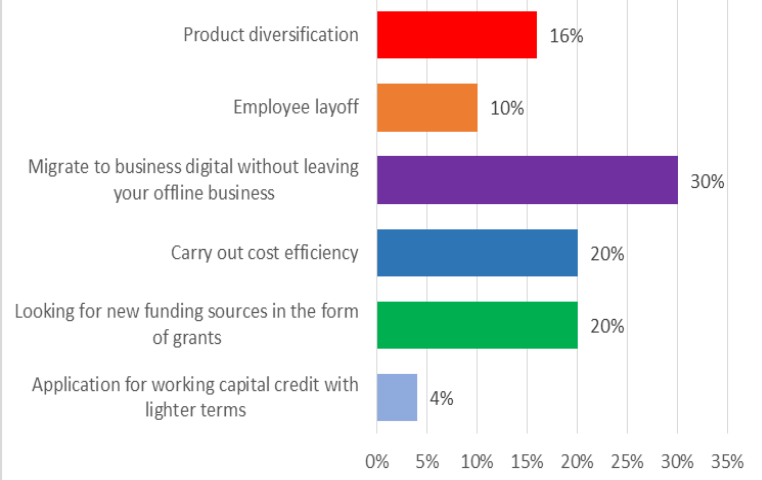

Fig.4. What has been done to get out of the Pandemic

When further investigated regarding their statement to switch to a digital business, the majority answered that they had used social media such as the Instagram shop or Facebook business to market their products $(80 \%)$. Meanwhile, the other efforts they have made in utilizing the advantages of technology for business benefits are still lacking. Even though they currently have a desire to build their own company website (20\%), in addition to utilizing online stores by joining the emarket place they have been running so far $(20 \%)$

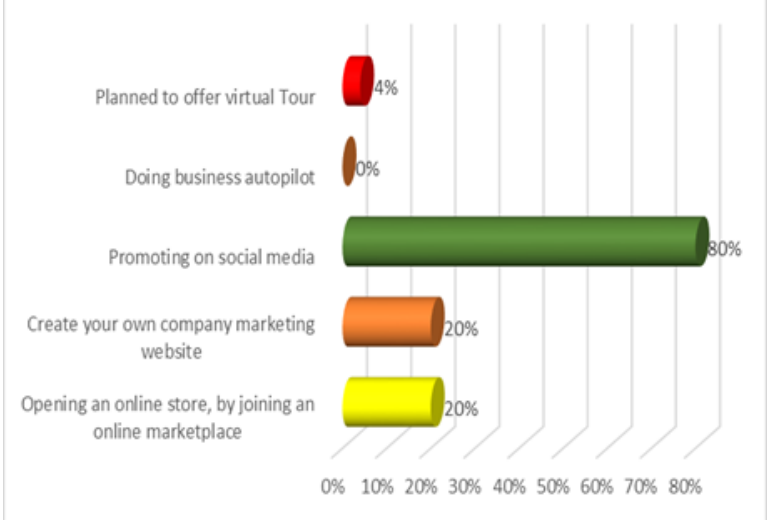

Fig. 5. Strategy Online

From the respondents' answers above, we can conclude that all have tried to keep their businesses running in these difficult times, including lowering selling prices and offset by steps to cut operational costs so that the reduced profit can still cover the existing cost needs. During the interview session, it was also revealed that it is very difficult to expect business from new customers. Therefore, efforts to re-establish relationships with old customers continue to be carried out while hoping that they will still make visits when the situation is getting better. In addition, the use of digital technology for companies engaged in the tourism industry is also very crucial. New opportunities are wide open when all activities take place online like now. Maximizing digital marketing is the best solution to maintain the company's image in the tourism world for both domestic and foreign guests. Because there are already several companies that are pioneering in creating and having their own websites, it is better to use the web and social media to display interesting, useful, as well as educative content. For example, browse YouTube channels with hotel reviews, web blog pages with light articles about destinations and travel tips, to microblogs about the history of tourist attractions on Instagram.

The application of adaptation to new habits (new normal) clearly changes the behavior of tourists when traveling. Likewise with the trend of Indonesian tourist destinations. Along with the easing of lockdown rules in various regions, slowly the hospitality \& tourism industry is expected to start throbbing again. Although not fully recovered, experts predict the following tourist destinations will attract tourist visits. Positioning selling tourist destinations in remote areas far from crowds such as hiking, climbing, or hidden beaches will be a tourist wish list [14]. The open nature allows them to maintain physical distance and avoid crowds of people, while also being able to breathe fresh air and not worry about being exposed to the corona virus. Along with the development of a new trend, namely vacationing at a hotel near home (Staycation) it can be used as a marketing policy suggestion by targeting millennials who are bored at home and want to change the 
atmosphere as the reason for those who choose a staycation as a tourist activity. As long as hotel managers are able to implement strict health protocols according to WHO standards, this option certainly opens the hopes of many parties [15].

Another trend that can be used as business diversification in the tourism industry is virtual tours utilizing VR (virtual reality) technology. Traveling to various world tourist destinations can now be done through virtual tours. If you can't take advantage of VR technology, virtual tours can be carried out through live social media or conference meetings. Top museums offer an online exploration of the building's special corners and collections. In fact, there are virtual tour operators complete with tour guides who are ready to accompany and share exciting stories throughout the session. This idea can be tried to add diversification of opinion to cover the revenue deficit due to the lack of guests who visit physically [16].

\section{Conclusion}

SME business owners who are engaged in tourism have tried to make various efforts to keep their business throbbing at the current time. From migrating and starting to take advantage of online businesses by opening an online shop to sell their products, making cost efficiencies to keep the company's cash flow liquid, trying to get additional loans as additional working capital, diversifying businesses outside the tourism business such as the fishery business and to do employee layoffs, although they will be rehired when conditions improve. However, all of these efforts have not been good enough, so they still hope for further assistance from the government in the form of support for business digitization, subsidizing employee wages,

Further efforts that can be made by tourism entrepreneurs are to maximize the use of virtual reality (VR) technology, so that tourists who do not yet have the ability to physically visit their pleasure tourism destinations can still enjoy them through virtual reality tours. Promoting the use of VR can reduce the possibility of spreading the virus, increase the sustainability of the destination, and provide other options for a wider audience of visitors to see how prospective and viable the site is. This company also generates alternative income. Innkeepers can take advantage of the staycation trend that is booming among millennial teenagers to vacation in hotels near their homes, while still implementing health protocols.

\section{References}

1. Litbang Kompas. Ekonomi-dunia-di-masapandemi-covid-19-dari-dampak-hingga-proyeksipertumbuhan-2021-2022 [Internet]. 2020. Available from: https://kompaspedia.kompas.id/baca/paparantopik/ekonomi-dunia-di-masa-pandemi-covid-19dari-dampak-hingga-proyeksi-pertumbuhan-20212022
2. D.W. Nugraha. Proyeksi bank dunia ekonomi indonesia tumbuh 44 persen tahun ini. KOMPAS [Internet]. 2021; Available from: https://www.kompas.id/baca/ekonomi/2021/03/26 /proyeksi-bank-dunia-ekonomi-indonesiatumbuh-44-persen-tahun-ini/

3. D. A. D. Nasution, E. Erlina, I. Muda. J Benefita. 5, 212-24 (2020).

4. S. A. Ni Kadek , S. D. Ni Nyoman. Kondisi ekonomi Indonesi -dimasa pandemi covid-19 [Internet]. 2021. a8452d541df489606ccd2/kondisi-ekonomiindonesia-dimasa-pandemi-covid-19

5. M. Irham. Virus corona: UMKM diterjang pandemi Covid-19 sampai "kembang kempis" [Internet]. 2021. Available from: https://www.bbc.com/indonesia/indonesia51946817

6. L. Iswari, M. Muharir, J Ilm Mhs Ekon Syariah. 1, 13-20 (2021).

7. W. Hadiwardoyo W. Baskara J Bus Entrep. 2, 8392 (2020).

8. N. F. Fabeil, K. H. Pazim, J. Langgat. J Econ Bus. 3, (2020).

9. K. Sandy. 72,6 Persen UMKM Turun Omzet akibat Pandemi Covid-19. (2021).

10. M. Albert. Australia's Economic Measures And Employment Laws Changes In Response To Covid-19 [Internet]. Covid-19 Pandemic: Labor and Employment Law measures around the world. Editora Conhecimento Livre; 2020. Available from: http://dx.doi.org/10.37423/200501001

11. LiveCareer Staff Writer. Government-policy [Internet]. 2020. Available from: https://www.livecareer.com/resources/careers/pla nning/government-policy

12. R. Hidayati, N. M. Rachman. Niagawan. 10, 1-9.

13. L. Susan, A. Madgavkar, J. Manyika, S. Smit, K. Ellingrud and OR. whats next for consumersworkers and companies $\mathrm{i}$-the post covid 19 recovery [Internet]. 2020. Available from: https://www.mckinsey.com/featuredinsights/future-of-work/whats-next-forconsumers-workers-and-companies-in-the-postcovid-19-recovery

14. J.J. Laird. Valuing the quality of strategic ferry services to remote communities. Res Transp Bus Manag [Internet]. 2012 [cited 2016 Jun 28];4:97103. Available from: http://www.sciencedirect.com/science/article/pii/S 2210539512000223

15. T.O. Priasni, D. Absharina, M. Rizal, Pd. Arnesia. Pros Sentik. 4, 49-56 (2020).

16. L.E. Potter, L. Carter, A. Coghlan. Virtual reality and nature based tourism [Internet]. Proceedings of the 28th Australian Conference on ComputerHuman Interaction - OzCHI '16. ACM Press; 2016. 